MIRROR IMAGING IN TWINS

Boklage CE (1981) On the timing of monozygotic twinning events. In L Gedda, P Parisi, and WE Nance (eds.): Twin Biology and Multiple Pregnancy. New York: Alan R Liss, pp. 155-165.

Brook AH (1984) A unifying aetiological explanation for anomalies of human tooth number and size. Archs. Oral Biol. 29:263-278.

Brown T, Townsend GC, Richards LC, Travan GR, and Pinkerton SK (1992) Facial symmetry and mirror imaging in South Australian twins. In T Brown and S Molnar (eds.): Craniofacial Variation in Pacific Populations. Adelaide: Department of Dentistry, Anthropology and Genetics Laboratory, pp. 79-98.

Carton A, and Rees RT (1987) Mirror image dental anomalies in identical twins. Br. Dent. J. 162:193-194.

Demirjian A, Goldstein H, and Tanner JM (1973) A new system of dental stage assessment. Hum. Biol. 45:211-227.

Garn SM (1977) Genetics of dental development. In JA McNamara (ed.): The Biology of Occlusal Development. Craniofacial Growth Series, Ann Arbor: The University of Michigan, pp. 61-88.

Graber LW (1978) Congenital absence of teeth: a review with emphasis on inheritance patterns. J. Am. Dent. Assoc. 96:266-275.

Hay DA, and Howie PM (1980) Handedness and differences in birth weight of twins. Perceptual and Motor Skills 51:666.

Nik-Hussein NN, and Salcedo AH (1987) Double teeth with hypodontia in identical twins. J. Dent. Child. 54:179-181.

Schneider PE (1985) Mirror-image twins with geminated incisors. Report of a case. Quintessence Int. 6:429-431.

Springer SP, and Deutsch G (1981) Left Brain, Right Brain. San Francisco: W.H. Freeman and Company.

Staley RN, and Green LJ (1974) Types of tooth cusp occurrence asymmetry in human monozygotic and dizygotic twins. Am. J. Phys. Anthropol. 40:187-196.

Townsend GC, Richards LC, and Brown T (1992) Mirror imaging in dentitions of twins - what is the biological basis? In T Brown and S Molnar (eds.): Craniofacial Variation in Pacific Populations. Adelaide: Department of Dentistry, Anthropology and Genetics Laboratory, pp. 67-78.

West VC (1985) Mirror image twins. Aust. Orthod. J. 9:243.

\title{
SPURIOUS "EXAMPLES" OF ANCIENT DENTAL IMPLANTS or APPLIANCES Part Two of a Series
}

MARSHALL JOSEPH BECKER

Department of Anthropology, West Chester University, West Chester, PA 19383, U.S.A.

ABSTRACT In addition to the various copies of ancient dental appliances, enormous numbers of reports deal with fanciful and unverifiable examples. These spurious dental bridges (or fake ancient crowns, inlays, or fillings) have been traced to their sources. While most of these spurious examples, such as the "stone" implant from Turkey (Atilla, 1993), discussed below, are found in the secondary literature, a few are accepted by scholars who were well versed in ancient dentistry (Guerini, 1909:68,n 1). In most cases, these spurious examples are the result of wishful thinking combined with poor referencing of earlier secondary sources, ignorance of the technology involved in the construction of dental appliances, and a lack of scholarly communication.

\section{SPURIOUS DENTAL IMPLANTS}

The classical literature is filled with references to ancient gold dental appliances in the CircumMediterranean region (Clawson, 1933; Becker, 1992; Ms. A), with the first documentation of discovery of an Etruscan gold dental appliance dating to the end of the 18th century (Böttiger, 1797). The archaeological verification of these publications appears to have spawned numerous reports which cannot be confirmed. Spurious accounts of ancient dental appliances were so common that Van Marter $(1885,1886)$ spent considerable time attempting to trace supposed Egyptian examples, which generally turned out to be amulets (Bonner 1950). Mummery (1870) had already discounted claims of early Egyptian examples, but the poor scholarship and the gullibility of authors over the decades has filled the literature with fanciful accounts. Weinberger's (1948:77-81) excellent review dismissed most of these tales, but he later generated still more mythical examples (Waarsenburg 1991:243, notes 13,20). A review of commonly noted examples of spurious dental appliances and implants appears below.

The "Dental Bridge" in the Skull of Pliny A skull with a non-matching mandible, together with "Pliny's sword," is now on display in the Museo Storico dell'Arte Sanitaria of the Accademia di Storia dell'Arte Sanitaria in Rome. Although, the provenance is imprecise (Waarsenburg, 1991), the skull and a mandible have been "identified" as belonging to Pliny the Elder, who died in the eruption of Vesuvius in 79 AD (Cannizzaro 1901; Micheloni 1976: 311). 


\section{SPURIOUS DENTAL APPLIANCES}

According to Baglioni (1952), evidence suggests that the mandible had been fitted with a dental bridge and had undergone oral surgery. In January of 1991, Dr. Waarsenburg took me to the Museo dell'Arte Sanitario in Rome to examine the mandible. No indication of any dental appliance, artificial drilling, or filing could be found in the mandible (Becker, Ms. B). Unfortunately, Waarsenburg's (1991) manuscript repeating the story about the dental bridge had already gone to press.

Baglioni's "Bridge" In addition to the "dental work" in the "skull of Pliny," Baglioni (1952:14-20) also suggested great antiquity for a gold dental plate with a set of 12 sockets purported to hold teeth, which came from "la campagna etrusco-laziale" in private hands. Bobbio (1958:370) gave the date for this piece as the Roman Imperial Period, but this clearly appears to be in error. This item may be an example of dentistry dating from after $1700 \mathrm{AD}$, the "golden" age of dental bridges.

The specimen now is missing or unknown (De Vecchio, 1939:85,fig.), but Bobbio (1958:370,fig.16) contains an illustration of the piece with a note stating that the object or the photograph was in the collection of Prof. S. Baglioni in Rome. In my opinion, given Baglioni's fabulation on the "skull of Pliny," one may discount this reference to ancient dentistry. Waarsenburg (1990:n.5,No.16, notes 5,8,n13), however, accepted Baglioni's statement and included this spurious "denture" in his inventory, thereby adding support for this second "spurious" example to the literature.

Cali's Creations Three spurious examples were created or listed in a single publication by Cali (1901). Since no other author has incorporated any of Cali's specimens into a subsequent inventory, all three are listed here together. They are a mummy (?) in Thebes found by Prof. Sanders about 1880 (Cali 1901:5), a maxilla from a mummy in the Meyer Museum in London (Cali 1901:10, and a specimen in the Vatican Museum (Cali 1901:11).

Cali's (1901:11) reference to a real specimen from the Museo di Papa Luigi, the Valsiarosa appliance shown in Figure 1 (Becker Ms. A:No.15), is one and the same as his piece from the Museo di Antichita“ nella Villa di Papa Giulio III. Cali believed they were 2 separate pieces, as did Weinberger (1948:125, 145), who attributed "one" to the Etruscans and the "other" to the Romans (see Waarsenburg 1990:note 20). Thus, the Valsiarosa appliance has multiplied in the literature.

Platschick's Piece from "Populonia" According to Waarsenburg (1990:n.1), Ghinst (1930) took this appliance from Valsiarosa, one of the less documented specimens, and "moved" it to a maxillary position. He then claimed that it came from a IV century BC context from Populonia.

Marzabotto near Bologna Count Pompeio Aria apparently provided Dunn (1894:4-5) with the following information (Waarsenburg, pers. com.). The Count had in his possession a gold pendant in the

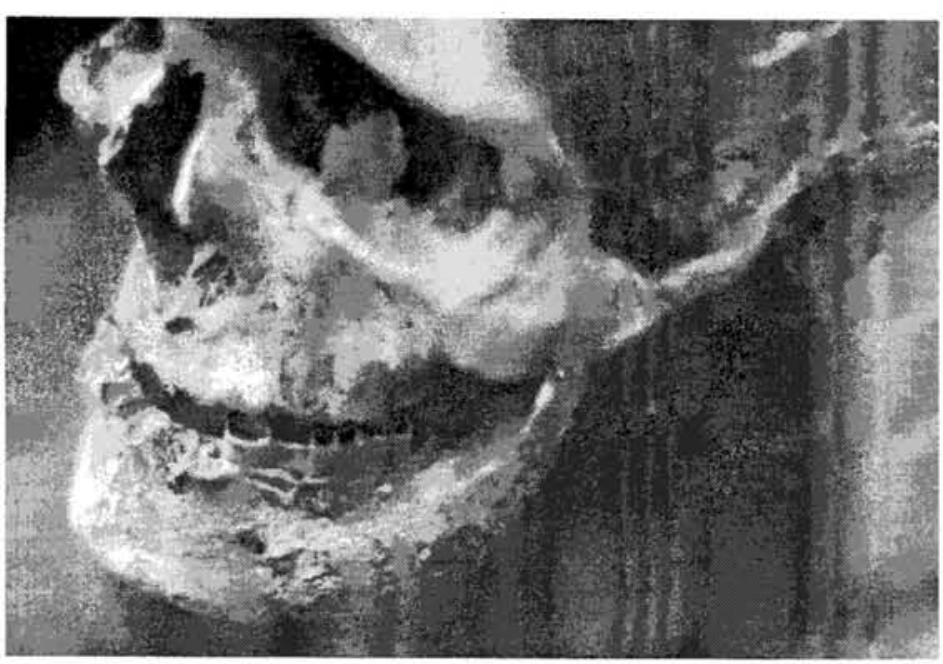

Fig. 1. Valsioroso appliance in the Museum in Civita, Castellana, Italy. The appliance does not derive from this skull. The appliance fit over four maxillary incisor spaces with a false tooth for a central incisor. However, the maxillary incisors for this skull were present at death. Note the rivet dividing the third "ring" from the left. Photo by M.J. Becker. form of a human incisor (Dunn 1894:4), which Platschick (1904-05:239) described as a deciduous tooth mounted in gold with a ring for suspension This pendant, which may have incorporated a real human tooth, is not a recycled dental appliance, as some authors suggest.

Count Aria also said that he once possessed a skull, which contained an artificial tooth attached with a gold wire (band?). According to Dunn (1894:5), "This skull was sent with other Etruscan objects to a foreign scientific society, but was never returned to Count Aria." However, Dunn (1894:4) indicated that he owned the skull and mandible with a complex gold band (from Poggio Gaiella) which he subsequently donated to the Museo Archeologico Etrusco in Florence (Inventory No. 11782), where it can be found today (Fig. 2). The 
appliance can now be demonstrated to have been made for another person, not for the skull in which it is now found (Becker MS. A:No.5).

Vetulonia "Crowns", Florence This series contains perhaps the most cited "examples" of artificial dentistry from antiquity. It consists of eleven human dental crowns from which the roots had deteriorated postmortem. All the teeth had been stained green from contact with a corroding copper or bronze coin placed in the mouth or from a bronze artifact that was part of the tomb offerings (Capasso, 1986:52). The teeth were found in four different tomb contexts, and thus represent at least four different people.

The teeth, were recovered from the Vetulonia necropolis area, northeast of Monte di Colonna (Falchi, 1885:98-114, 398-417, Tav. VI, XII, VII-IX; Levi, 1931; Casotti, 1957, fig. 1). They are now in the collections of the Etruscan Archaeological Museum, Florence (Inventory Nos. 7820-7824; Bliquez, in press). Early references on the teeth include Dunn (1894:3) and Falchi (1885, 1891, 1908).

Several reviews of archaeological data and interpretations of the stained teeth contain conclusions that the teeth are human dental crowns, stained from contact with bronze, whose dentine and roots had disintegrated postmortem (Platschick, 1904-05:239, fig. 1; Brown, 1934:958-9; Weinberger, 1941:1853; Casotti, 1957:105-111, fig. 7, citing Falchi, 1891:67; Bobbio, 1958:368, fig. 15 from

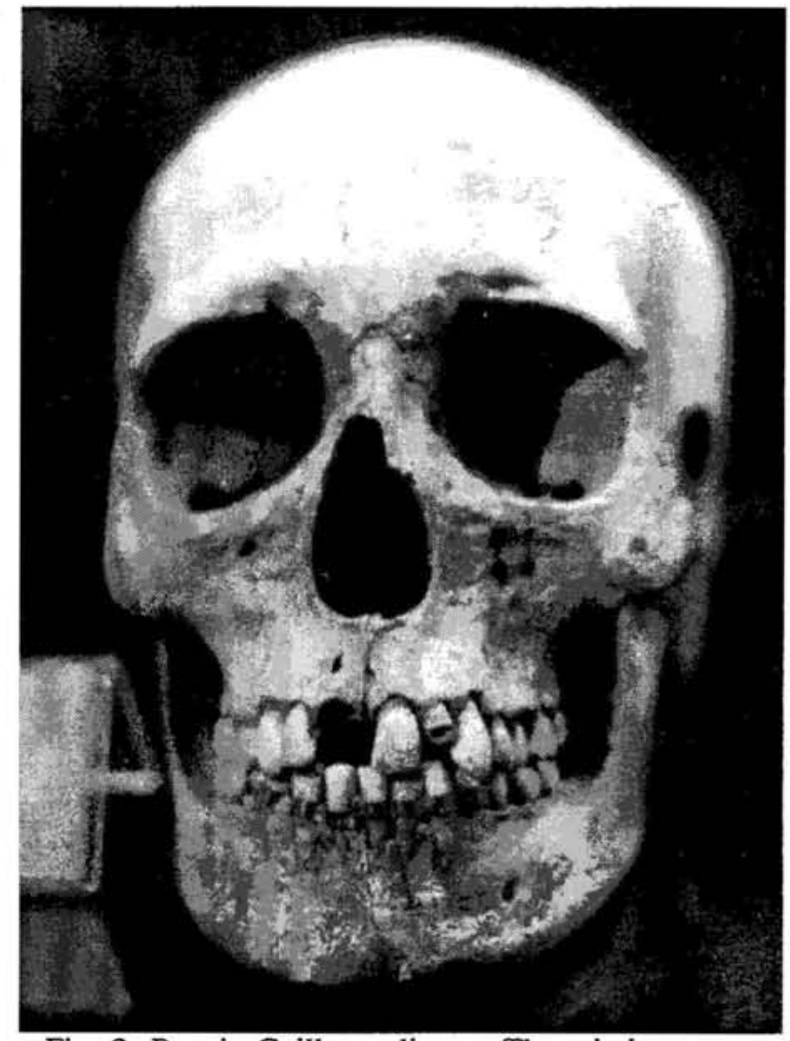

Fig. 2. Poggio Gailla appliance. The missing maxillary incisor is a post-mortem loss. This appliance (or appliances) is not original to this skull. Photo by M.J. Becker. Casotti, 1957). However, the teeth have also been identified incorrectly as early artificial cast gold crowns or a dental appliance by Guerini (1909:70, figs.13, 14), who may have been confused by the metallic appearance of the teeth (Bliquez, in press), and as appliance from Chiusi by Ghinst (1930:406). Therefore, these teeth remain imbedded as an "appliance" in the literature (Boissier, 1927:25, fig.1; Tabanelli, 1963:92,Tav.49; Emptoz, 1987:546).

Falchi's (1891:Tav. XIV, 15) report on Vetulonia also contains an illustration of two teeth that look like those of a small dog. The possible band binding these teeth, if the sketch is accurate, may reflect their use as a charm. These small teeth clearly are not those of a dog, and may represent human teeth bound in an actual appliance. However, what appliance may be indicated is unclear. Also not a dental appliance are the crowns of four human teeth with the roots reconstructed are shown in Falchi (1885:Tav. VII, Tav. XV, 2 and XVII). However, according to Falchi $(1891: 67,68,309)$, the graves from which three "human" teeth derive may actually have produced material from a necklace.

The Purland "Egyptian" Examples Purland (1857) reported that he had a "pivot" tooth from the "head of a mummy in the collection of a lamented friend." A "pivot" tooth is a false crown affixed to a natural root by means of a gold post or "pivot." Brown (1934:830-831) clearly indicated that the date and origin of such an example must be considered unreliable. What Purland identified as a false tooth remains unknown.

Purland (1857/1858:I:63) also repeated the story that Belzoni had found false teeth and teeth filled with gold in Egyptian mummies and reported that examples of dental prostheses existed in the collection of Joseph Mayer in Liverpool (Becker Ms. A:Nos. 13 and 14) and in collections in Berlin and Paris. Aside from the true appliances in Mayer's collection, these other "examples" may refer to gold items associated with mummies. However, evaluations of them as actual appliances cannot be determined. Meanwhile, Purland's claims to ancient Egyptian examples of dental prostheses unfortunately have been cited as if they were valid (Perine, 1883:163; Casotti, 1947; Micheloni, 1976:159). 
Other Spurious Ancient Egyptian Examples Supposedly from before the Hellenistic Period As noted previously, a vast literature stating that "ancient" Egyptians possessed dental prostheses exists. Textual evidence suggests that the Egyptians were not pulling teeth, but were practicing complex oral medicine as early as $2,900 \mathrm{BC}$ (Jonckheere, 1958). However, no evidence for dental appliances before 600 $\mathrm{BC}$ can be documented, and none of the early examples are from Egypt. Artifacts most commonly mistaken for dental appliances are votive objects, which are the subject of another paper.

Quenouille (1975) effectively discounted the possibility that these Egyptian artifacts were anything else than votives and Bardinet (1990) has summarized direct evidence discounting many spurious claims. However, Trillou (1976) reported questionable and indirect "evidence" in an attempt to prove that early examples of dental prostheses existed in Egypt. Another repetition of the misconceptions involving several of these votives appears in Puech, Cianfrani, and Puech (1970:2006).

St. Benedict's Dentures St. Benedict, the founder of the Benedictine Order, who died in 543, is often claimed to have worn dentures or a dental appliance. Brown $(1934: 835, n 6)$ examined the skull and found no evidence for this story.

The Nabatean "wire implant" A skull of a male from a mass grave in the northern Negev, dated to $200 \mathrm{BC}$, was found with a bronze wire approximately $2.5 \mathrm{~mm}$ in length firmly implanted in the canal of a maxillary right lateral incisor (Zias and Numeroff, 1986a,b, 1987). Zias and Numeroff suggest that the pin had been deliberately inserted after artificially expanding the chamber; in effect, as a primitive root canal operation or an attempt to prevent 'tooth worms'. The authors also suggest that the wire may have been a pin to hold an artificial tooth in place, or that something had been done (drilling?) to provide a drain for a large palatal cyst which they identified at the root of the tooth.

All of these inferences are equally unlikely, given what is known about the state of dental medicine and technology at that time. None of the implants has been demonstrated through scanning electron microscopy or other techniques which might confirm these speculations. Equally unlikely is the insertion of a bronze pin, or even a gold pin, for any of the tasks suggested by Zias and Numeroff (1986a,b, 1987). A remote possibility that a false crown might have been mounted on this tooth exists, but this idea also is unlikely. Powers (1989) clearly pointed out these errors, and noted another similar example from Lackish (British Museum BM1944.1.20.518), which is believed to have resulted from an accidental situation.

Another case of an insertion in a tooth has been reported from the Aebelholt monastery in Denmark. According to Bennike (1985), a "bead" (or "pearl") was found "fixed into a caries cavity" from a medieval context (Møller-Christensen, 1958). Later, Bennike (1986:81) quoted Møller-Christensen (1969) as having reporting this medieval "implant" as a deliberately placed "pearl." One may infer that this "pearl," like the "bronze wire" noted above, found its way into this context by accident, as no reasonable dental treatment appears to have been intended in this situation.

The "Stone Implant" from the Kalabah Necropolis, Klozomenai, Turkey This stone, thought to be the size and general shape of a maxillary right canine, was found in a looted limestone sarcophagus with a limestone lid (Tomb Nr. 81/6) in the Kalabak Necropolis (Atilla, 1993). The site is situated to the east of the ancient Ionian city of Klozomenai on the Aegean coast. The date is given as $550 \mathrm{BC}$, based on the placement of the tomb over a cremation burial (Tomb Nr. 81/3) which contained associated materials dated to the first half of the sixth century BC (600-550 BC). Although no inventory of osteological or dental materials were given, Atilla (1993) reported that the individual was female due to the presence of a gold hair spiral and between 14 and 16 years old from eruption of mandibular teeth.

Geological studies demonstrated that the stone seems to be composed of a hematite travertine portion and a calcite section, the latter probably representing the pseudo-crown. Calcite is noted as having a hardness of 3 on Moh's scale, which is quite soft. The "crown" measures $6 \times 5 \times 11 \mathrm{~mm}$, and fractures seen on it under a stereomicroscope are said to have led to the theory that this object had functioned as a tooth.

The anatomical identification of the stone "crown" was inferred from its length of $29 \mathrm{~mm}$ which Atilla (1993) suggested as "the same" as is generally noted for upper canines and from its "inclination" (bevel of the area believed to be the crown?). The shape of the stone, which Atilla (1993) says does not exist in nature, has led to the suggestion that the implant was attached to the adjacent tooth with special wires or 


\section{SPURIOUS DENTAL APPLIANCES}

devices. Moreover, the neck area of the stone is believed to contain "erosion lines resulting from the gold wire or band" and a polarizing light microscope is said to have revealed "gold pieces a few microns in diameter," supposedly traces of a gold fastening. An artist's drawing (Atilla 1993:fig. 3) depicts the stone as wired to the upper right lateral incisor and first premolar.

I would place the date, given the evidence, at $600-550 \mathrm{BC}$, which is well within the period when the earliest examples of Etruscan dental appliances are known. Since one of these appliances was recovered from a Greek context (the Eretria example, from Euboea), an example from one of the famous Ionian cities such as Klozomenai is entirely possible. In addition, the Etruscan examples all were worn by women, strongly suggesting that decoration and vanity were motivating factors, but none of the documented examples derive from the burial of an adolescent.

However, none of the other evidence from this tomb appears at all convincing. Although this piece of stone is said by Atilla to have been "carved," he reported that it "did not resemble a piece of an ornament." In addition, although the report contained the observation that such an artifact does not occur in nature, such pieces are found by amateur archaeologists and interested geologists with great frequency. In my opinion, this clearly is a natural stone, differentially eroded (not worked), and with a slight resemblance to a tooth.

As mentioned, the stone was thought to have been bound in place by a gold wire similar to those known from various Phoenician locations. The reported traces of gold at the neck of this object may indicate that it was bound in a gold devise, but gold actually may be part of the mineralogical composition of the stone. None of the adjacent teeth (if such existed) were tested to support the theory that this stone was bound in place by a gold ligature.

At $29 \mathrm{~mm}$, this stone piece clearly is too long to have served as a false tooth in a bridgework unit. Artificial teeth are always limited to the crown portion alone, being suspended in a pontic devise by bands in the Etruscan designs or by wires in Phoenician examples.

The stone of this tooth also is far too soft to have functioned as an artificial tooth. The preferred materials were ivory, human or animal teeth, and very dense woods. Gold was used in the singular tooth from Satricum, the earliest known dental appliance. Problems involved with the soft gold shell such as employed in the Satricum example probably rapidly led to the use of more durable materials. Despite the claim that stone has been used for other dental pontics, no such documented case can be verified.

Most likely this piece of stone was a chance inclusion within the opened sarcophagus, either entering when the tomb was looted or at another point when the box was open. Also possible is that some ancient, such as a young girl, found this interesting stone and carried it as a charm. Far from being a "dental implant," the stone artifact noted by Atilla appears to be one of the large number of spurious objects suggested as representing examples of ancient dental technology.

\section{SUMMARY AND CONCLUSIONS:}

Some 25 ancient dental appliances are known from throughout the Mediterranean region. All of these fall into two distinct major categories: Etruscan bands and Phoenician wires. "Spurious" examples exist as well. These spurious examples derive from incorrectly identifying artifacts, stone, and other objects as dental appliances, as well as through "creation" of "new examples" through the printing of illustrations in reverse or upside down. This article has identified eleven such examples and shown how their number has been augmented by such factors as imprecise reports and repetitions of published errors.

\section{LITERATURE CITED}

Atilla G (1993) A rare find in Anatolia - A tooth implant (mid-Sixth Century B. C.). Journal of Oral Implantology 19(1):54-57.

Baglioni S (1952) Contributi alla conoscenza dell'arte dentaria àntica II. Atti e Memorie dell'Accademia di Storia dell'Arte Sanitaria (series 2), 18(2):14-74.

Bardinet T (1990) La prothese dentaire au temps des pharaons: Mythe ou realite? L'Information Dentaire 29(19 juillet $): 2553-2555$.

Becker MJ (1992) An Etruscan gold dental appliance in the collections of the Danish National Museum: Evidence for the history of dentistry. Tandlaegebladet: Danish Dental Journal 96(Nr. 15):Cover, 695-700.

Becker MJ (Ms. A) Ancient Dental Appliances in the Mediterranean. Ms. in review for Studi Etruschi. 


\section{SPURIOUS DENTAL APPLIANCES}

Becker MJ (Ms. B) The "Skull of Pliny" in the Museo Storico Nazionale dell'Arte Sanitaria, Rome (field notes, 3 January 1991).

Bennike P (1985) Paleopathology of Danish skeletons. A Comparative Study of Demography, Disease and Injury. Copenhagen: Akademisk Forlag.

Bennike P (1986) Dental treatment in the Stone Age. Bulletin of the History of Dentistry 34(2):81-87.

Bliquez L (In press) Prosthetics in Classical Antiquity. In W Haase (ed.): Aufstieg und Niedergang der römischen Welt.

Bobbio A (1958) Excurso histórico da prótese dental fenícia, Etrusca e Romana. Revista da Associacão Paulista dos Cirurgiões Dentistas 12(6):360-374.

Boissier R (1927) L'evolution de l'Art Dentaire de l'antiquité a nos jours. Paris: La Semaine Dentaire.

Bonner C (1950) Studies in Magical Amulets, Chiefly Graeco-Egyptian. Ann Arbor: University of Michigan Press.

Böttiger CA (1797) Griechische Vasengemälde. Mit archäologischen und artistischen Erläuterungen der Originalkupfer. Ersten Bandes, Erster Heft. Weimar: Industrie-comptoir. (IV Nachrichten über die griechischen Vasen aus Briefen von Tischbein und Meyer (3. Jan. 1796: Naples).

Brown LP (1934) The antiquities of dental prosthesis (Part I: To the close of the Fifteenth Century; Part II: Sixteenth and Seventeenth Centuries; Part III: Sections I and II). Dental Cosmos 76:828-836, 957-966, 1078-1084, $1155-1165$.

Cali G (1901) L'odontoiatria attraverso i secoli. Naples: [Tipografia dell'Unione].

Cannizzaro M (1901) Il cranio di Plinio. London: Private edition.

Capasso L (1986) Etruria: Le Meraviglie dei Dentisti. In, "La Medicina nell'Antichità." Archeo Dossier [Novara] 13:52-55.

Casotti L (1947) L'Odontotecnica degli Etruschi. Rivista Italiana di Stomatologia 2(8):661-678.

Casotti L (1957) Vetulonia Etrusca e stomatologia. Rivista Italiana di Stomatologia 12(1):97-112.

Clawson MD (1933) A Phoenician dental appliance of the 5th Century, BC. Transactions of the American Dental Society of Europe. pp. 142-160.

De Vecchio B (1939) La scoperta di un nuovo apparecchio protesico dell'Epoca Romana. La Stomatologia Italiana 1:84-85.

Dunn CG (1894) L’Arte Dentaria fra gli Etruschi. Firenze: G. Barbéra.

Emptoz F (1987 ) La Prothèse Dentaire dans la Civilisation Étrusque. Archéologie et Médecine: VII Recontre Internacionales d'Archéologie et d'Histoire (Antibes 1986). Editions A.P.D.C.A.: Juan-les-Pins, pp. 545-560.

Falchi I (1885) V. Colonna [Necropoli di Vetulonia in Colonna], pp. 98-114. IV. Colonna [Necropoli di Vetulonia], pp. 398-417. Notizie degli Scavi di Antichita for 1885.

Falchi I (1891) Vetulonia e la sua necropoli antichissima. Firenze: Edizione Anastatica (Reprinted 1965, Roma: "L'Erma" di Bretschneider).

Falchi I (1908) Scavi a Vetulonia. Notizie degli Scavi di Antichita V:419-437.

Ghinst J van der (1930) Les Etrusques, connaissent-ils la pyorrèe e la methode prosthetique du traitement? Atti VIII Congresso internazionale di storia della medicina. Rome: Istituto poligrafico dello stato, pp. 322-408.

Guerini V (1909) A history of dentistry from the most ancient times until the end of the eighteenth century. Philadelphia: Lea and Febiger.

Jonckheere F (1958) Les médecins de l’Égypte pharaonique: Essai de Prosopographie. La Médecine Egyptienne, No. 3. Brussels: Fondacion Egyptienne Reine Elisabeth.

Levi D (1931) Carta archeologica di Vetulonia. Studi Etruschi 5:13-40.

Micheloni P (1976) Storia dell'odontoiatria. Volume I: Dalla preistoria al tempo di Roma. Rome: Tipografia Editrice Italia.

Mummery JR (1870) On the relations amongst the ancient inhabitants. Transactions of the Orthodontic Society of Great Britain 2:22.

Møller-Christensen V (1958) Bogen om Aebelholt Kloster. Copenhagen: Dansk Videnskabs Forlag.

Møller-Christensen V (1969) Tandpleje i middelalderen [Dental treatment in the Middle Ages]. Nordisk Medicinhistorisk Aarsbok, Supplement II.

Perine G (1883) A history of dentistry from the earliest period to the present time. New England Journal of Dentistry 2(6): 161-166, 199-205, 269-273, 343-345.

Platschick Carlo (1904-05) La via percorsa dall'odontoiatria (Section I Primo Trattato Italiano di Odontotecnica). La Stomatologia 3:237-256.

Powers R (1989) Operative dentistry in the second century BCE. Paleopathology Newsletter 63:13-14.

Puech P-F, Cianfarani F, Puech S (1990) Les Dents, des singes à Mozart. L'Information Dentaire 72 (22):2003-2008.

Purland Jr'T (1857/1858) Dental memoranda. Quarterly Journal of Dental Science I:63-65, 201-204, 342-346, 460-463; II [1858]:121-123, 242-243, 353-355, 490-493.

Quenouille J-J (1975) La Bouche et les dents dans l'Antiquite' égyptienne. Doctoral Thesis (Dental Surgery) University Claude-Bernard, Lyon (No. 437), France.

Sgarbi V (ed.) (1984) Tutti i musei d'Italia. Rozzano: Editoriale Domus. Tabanelli, Mario N

Tabanelli Mario N (1963) La Medicina nel Mondo degli Etruschi. Firenze: Leo S. Olschki.

Trillou J-A (1976) La prothèse dentaire égyptienne: mythe où réalité? Le Chirurgien-Dentiste de France (24 March). pp. $59-60$.

Van Marter JG (1885) Some evidences of prehistoric dentistry in Italy. Independent Practitioner 6:1-5(preceeded by plates),

Van Marter JG (1886) Further evidences of prehistoric dentistry. Independent Practitioner 7:57-61 and plate.

Waarsenburg DJ (1990) Auro dentes iuncti: An inquiry into the study of the Etruscan dental prosthesis. In M Gnade (ed.): Stips Votiva. Amsterdam: Allard Pierson Museum, University of Amsterdam, pp. 241-247.

Waarsenburg DJ (1991) De Schedel van Plinius Maior. Hermeneus 63(I):39-43.

Weinberger BW (1941) The Etruscan cast "gold" crowns illustrated by Guerini. J Am Dent 28:1853-1854.

Weinberger BW (1948) An Introduction to the History of Dentistry. Volume 1. St. Louis: C. V. Mosby (Special edition by Gryphon Editions in Birmingham, Alabama, 1981.

Zias JE, and Numeroff K (1986a) Case reports on paleopathology: No. 7. Paleopathology Newsletter 53:10-11.

Zias JE, and Numeroff K (1986b) Ancient dentistry in the Eastern Mediterranean. Israel Exploration Journal 36:65-67.

Zias JE, and Numeroff K (1987) Operative dentistry in the second century BCE. J Am Dent 114:665-666. 